\title{
MEMBANGUN KARAKTER MULIA PADA ANAK: \\ PERTIMBANGAN PENGENALAN HUKUM ISLAM \\ SEMENJAK DINI
}

\author{
$\underline{\text { Rosdiana }}$ \\ Universitas Islam Negeri (UIN) Syarif Hidayatullah Jakarta \\ E-mail: ros_sha2009@yahoo.com
}

\begin{abstract}
This writing elaborates the introduction of Islamic Law towards children as an attempt to build a noble character on them. The noble character or "akblaq" in Islam is a result of implementing process in sharia (ibadah and muamalab) based on the strong foundation known as "aqidab" in Islam. Furthermore, all of the sharia stipulation grounded on the implementation of akhlaq and noble character. The relevance of the Islamic Law introduction and the character building is able to integrated through religion education tanght by parents, school, and society. Moreover, religion education is considerably inadequate if it only concerns on the cognitive aspect, it also needs to learn about the emotional intelligence of the children. Thus, the importance of children understanding on Islamic Law is performed that the children could have a self-awareness towards the globalization, they could differentiate the right and wrong, and be able to make a great decision in their life, family, even society. Besides, the problems of religion education which tends to be more theoretic cannot be effective enough to be a ground of character building. So, Islamic Law for more mature children needs to be introduced through strengthening the right religious education. This writing, psychologically and philosophically, would like to address the significant point of introducing the Islamic Law to children. Therefore, parents and other environments have a great role in giving the examples about the studied materials.
\end{abstract}

\section{Keywords: Islamic Law, Education, Children Character}

\section{PENDAHULUAN}

Persoalan pendidikan tampak begitu mengemuka dalam kehidupan masa kini. Kualitas anak yang merupakan generasi penerus bangsa kerap dipertanyakan dan diperbincangkan. Ironisnya, generasi muda Indonesia berubah menjadi lebih beringas, di mana anak sudah bisa membunuh teman sebaya, berani membunuh orangtua, memperkosa adik atau bahkan ibunya, serta tindakan lainnya, yang menggambarkan terjadinya degradasi moral, nilai dan karakter pada anak. Hal ini tentu menguatkan asumsi semakin terkikisnya karakter anak sebagai insan suci tanpa dosa. Pemahaman anak terhadap hukum nampaknya tentu masih sangat minim.

Krisis moral ataudemoralisasi pada anak terjadi akibat dari kurangnya penguatan pendidikan agama yang diberikan oleh orangtua maupun lingkungan anak. Dari banyak hasil penelitian, banyak pakar, filsuf, dan orang-orang bijak menyatakan bahwa faktor moral adalah hal utama yang harus dibangun terlebih dahulu agar bisa membangun sebuah masyarakat yang tertib, aman dan sejahtera.

Persoalan kehancuran bangsa tidak dapat diatasi dengan doa atau membaca kitab suci. Dibutuhkan seseorang yang beragama dan berkarakter dalam mengatasi hal tersebut. Nilai-nilai agama dan nilai demokrasi bukanlah sesuatu yang harus dipertentangkan. Jika dipahami secara utuh, nilainilai ini dapat memberikan sumbangan yang efektif bagi sebuah penciptaan masyarakat yang stabil dan mampu bekerjasama dalam mencapai tujuan bersama. Oleh karena itu pendidikan agama merupakan dukungan dasar yang tak tergantikan bagi keutuhan pendidikan karakter, karena dalam agama terkandung nilai-nilai luhur yang mutlak kebaikan dan kebenarannya. 
Pembentukan karakter merupakan salah satu tujuan pendidikan nasional. Pasal 1UndangUndang No.20 Tahun 2003 tentang Sistem Pendidikan Nasional menyatakan bahwa di antara tujuan pendidikan nasional adalah mengembangkan potensi peserta didik untuk memiliki kecerdasan, kepribadian dan akhlak mulia.Amanah undang-undang tersebut bermaksud agar pendidikan tidak hanya membentuk insan Indonesia yang cerdas, namun juga berkepribadian atau berkarakter, sehingga nantinya akan lahir generasi bangsa yang tumbuh berkembang dengan karakter yang bernafas nilainilai luhur bangsa serta agama.

Isu pendidikan karakter di Indonesia semakin hangat diperbincangkan dalam kurun lima tahun terakhir selama berturut-turut, terutama tahun 2010-2011. Balitbang Kementerian Pendidikan dan Nasional (sekarang: Kementerian Pendidikan dan Kebudayaan), bahkan mengeluarkan buku kecil berjudul Panduan Pelaksanaan Pendidikan Karakter. (Kemendiknas, 2011). Penekanan terhadap pendidikan karaktermenjadi bagian penting yang sering terlupakan dalam proses pendidikan selama ini. Padahal substansi dari pendidikan itu sendiri adalah proses untuk mengembangkan watak optimisme dalam diri manusia, memberikan kesadaran kritis agar manusia mampu mengembangkan penalaran, memanggil kepada manusia akan kebenaran hakiki, dan memberikan pencerahan iman serta akal budi manusia. (Abdurrahmansyah, 2004:179).

Banyak pakar mengatakan bahwa kegagalan penanaman karakter sejak usia dini akan membentuk pribadi yang bermasalah di masa dewasanya kelak. Selain itu, menanamkan moral kepada generasi muda adalah usaha yang strategis. Oleh karena itu penanaman moral melalui pendidikan karakter sedini mungkin kepada anak-anak adalah kunci utama untuk membangun bangsa.

Maka salah satu kewajiban utama yang harus dijalankan oleh orangtua kepada anak adalah memberikanpenguatan nilai-nilai moral yang akan membentuk karakter pada anak. Karakter yang berkualitas ini tentu perlu dibentuk dan dibina sejak usia dini. Usia dini merupakan masa kritis bagi pembentukan karakter seseorang. Hasil penelitian menunjukkan bahwa sekitar $50 \%$ variabilitas kecerdasan orang dewasa sudah terjadi ketika anak berusia 4 tahun. Peningkatan 30\% berikutnya terjadi pada usia 8 tahun, dan 20\% sisanya pada pertengahan atau akhir dasawarsa kedua (Suyanto, 2010).

Pada usia 0-6 tahun, otak manusia berkembang dengan sangat cepat hingga 80\%. (Bloom, dalam Depdiknas, 2010). Pada usia tersebut, otak menerima dan menyerap berbagai macam informasi, tanpa melihat apakah informasi itu baik atau buruk. Pada usia ini, seorang anak akan sangat sensitif dan peka dalam mempelajari dan meniru sesuatu yang dilihat, dirasakan, dan didengarkan dari lingkungannya. Itulah masa-masa dimana perkembangan fisik, mental, maupun spiritual anak akan mulai terbentuk yang sering dinamakan sebagai masa emas anak (golden age). Pada usia tersebut, anak tentu sudah harus diberi pengenalan terhadap agama.Bahkan Abdullah Nashih Ulwan menekankan pentingnya pemahaman orangtua tentang perkawinan karena sangat berhubungan dengan pendidikan anak kelak. Menurutnya, perkawinan adalah kepentingan sosial karena mampu menyelamatkan masyarakat dari penyimpangan akhlak (Ulwan, 2013:5).

Maka, aspek penting yang perlu ditanamkan kepada anak sejak usia dini adalahiman (melalui pendidikan agama) dan akhlak (melalui pendidikan karakter). Menurut Wahab (dalam Hamid dan Saebani, 2013:30), istilah karakter sama dengan istilah akhlak dalam pandangan Islam.Karakter atau akhlak mulia merupakan suatu hasil yang dihasilkan dari proses penerapan syari'ah (ibadah dan muamalah) yang dilandasi oleh fondasi aqidah yang kokoh dan bersandar pada al-Quran dan asSunnah.

Perlu diketahui bahwa hukum Islam diwajibkan kepada anak yang sudah baligh atau sudah berusia 15 tahun, sebagaimana yang dijelaskan oleh Imam Syafi'i dalam bukunya, al-Umm. (Syafi'i, 
2000:165).Beliau menafsirkan bunyi Q.S al-Isra' [17]: 6, surat al-Nur [24]:197, dengan membandingkan kepada suatu riwayat hadits yang menjelaskan bahwa Allah telah mewajibkan jihad, kemudian Rasul menyuruh orang-orang yang telah berumur lima belas tahun untuk berjihad, termasuk ibnu Umar yang telah mencapai umur 15 tahun. Adapun ayat yang menjelaskan tentang hal tersebut adalah sebagai berikut:

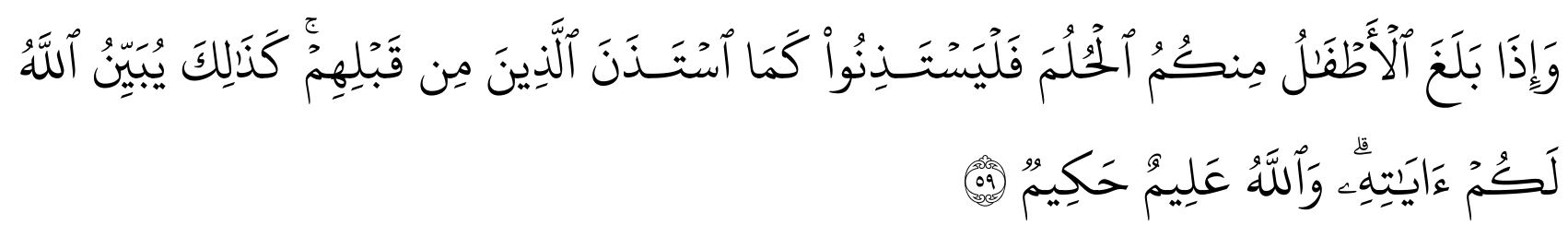

Artinya: "Dan apabila anak-anakmu telah sampai umur balig, maka hendaklah mereka meminta izin, seperti orang-orang yang sebelum mereka meminta izin. Demikianlah Allah menjelaskan ayat-ayat-Nya. Dan Allah Maha Mengetabui lagi Maba Bijaksana”. (QS. An-Nuur [24]:59).

Namun pengenalan mengenai halal haramnya suatu tindakan kiranya perlu dikenalkan kepada anak semenjak dini agar anak bisa lebih terdidik.Hal ini didasarkan pada fenomena perkembangan anak usia dini yang mengalami pendewasaan bukan pada waktunya. Karena hukum Islam atau syari'at pada prinsipnya mengacu kepada kemaslahatan manusia. Tujuan utama syari'at Islam (maqashid alsyari'ab) adalah untuk mewujudkan kemaslahatan umat manusia, baik di dunia maupun di akhirat. Hal ini sesuai dengan misi Islam secara keseluruhan yang rahmatan li al-alamin. Sebagaimana Al-Syatibi dalam al-Muwafaqat-nya menegaskan, "telah di ketahui babwa diundangkannya syari'at Islam adalab untuk mewujudkan kemaslahatan makbluk secara mutlak."(Asy-Syatibi, t.t.)

Maka dalam usia yang masih dini tersebut, kiranya perlu bagi orangtua untuk memanfaatkan masa emas seorang anak dengan mulai memberikan pendidikan karakter yang baik bagi anak. Pendidikan karakter yang diberikan kepada anak sejak usia dini bukanlah suatu hal yang dilakukan untuk mengekang dan menekan fitrah seorang anak, tetapi bertujuan untuk mengembangkan potensi positif pada anak yang bersesuaian dengan fitrah anak yang hanif(condong pada kebenaran).

\section{PEMBAHASAN}

\section{Pendidikan Karakter dalam Perspektif Islam}

Kata karakter berasal dari kata Yunani "charassein" yang berarti mengukir sehingga terbentuk sebuah pola(Ryan dan Bohlin, 1999:5, Echols dan Shadily, 1995:214). Menurut Pusat Bahasa Departemen Pendidikan Nasional, karakter adalah bawaan, hati, jiwa, kepribadian, budi pekerti, perilaku, personalitas, adat, tabiat, tempramen, dan watak. (Amir, 2011:3).Karakter ini menurut Thomas Lickonameliputi pengetahuan tentang kebaikan (moral knowing), lalu menimbulkan komitmen (niat) terhadap kebaikan (moral feeling), dan akhirnya benar-benar melakukan kebaikan (moral behavior)(Lickona, 2012).

Dalam Islam, pendidikan karakter perlu dilakukan. Istilah karakter memiliki dua pengertian; sebagai tingkah laku, dan karakter yang berkaitan erat dengan kepribadian (Mu'in, 2011:160). Karakter dalam bahasa Arab diartikan khuluq, sajiyyah, thab'u yang dalam bahasa Indonesia diterjemahkan dengan syakhshiyyah atau personality, yang artinya kepribadian. Namun Dennis Coon dalam bukunya, Introduction to Psychology: Exploration and Aplication, membedakan antara kepribadian dan karakter, di mana menurutnya kepribadian adalah hadiah dari Tuhan Sang Pencipta saat manusia dilahirkan dan setiap 
orang yang memiliki kepribadian pasti ada kelemahannya dan kelebihannya di aspek kehidupan sosial dan masing-masing pribadi. Kepribadian manusia secara umum ada 4, yaitu: Koleris, Sanguinis, Phlegmatis, dan Melankolis. Sedangkan karakter akan muncul saat setiap manusia belajar untuk mengatasi dan memperbaiki kelemahannya, serta memunculkan kebiasaan positif yang baru, misalnya, seorang dengan kepribadian Sanguin yang sangat suka bercanda dan terkesan tidak serius, lalu sadar dan belajar sehingga mampu membawa dirinya untuk bersikap serius dalam situasi yang membutuhkan ketenangan dan perhatian fokus, itulah Karakter. Seorang anak membutuhkan pendidikan karakter karena pada perkembangan seorang anak adalah mengembangkan pemahaman yang benar tentang bagaimana dunia ini bekerja, mempelajari "aturan main" segala aspek yang ada di dunia ini. Anakanak akan tumbuh menjadi pribadi yang berkarakter apabila dapat tumbuh pada lingkungan yang berkarakter.(Coon, 2010:393).

Secara akademis, pendidikan karakter dimaknai sebagai pendidikan nilai, pendidikan budi pekerti, pendidikan moral, pendidikan watak atau pendidikan akhlak yang bertujuan mengembangkan kemampuan peserta didik, untuk memberikan keputusan baik dan buruk, memelihara apa yang baik itu dan mewujudkan kebaikan itu dalam kehidupan sehari-hari dengan sepenuh hati. Karena itu, muatan pendidikan karakter secara psikologis mencakup moral reasoning, moral feeling, dan moral behavior (Lickona, 2012:74).

Adapun dalam pandangan Islam, tidak ada disiplin ilmu yang terpisah dari etika Islam. Maka sangat perlu mengombinasikan antara akal dan wahyu dalam menentukan nilai-nilai moral. Akhlak merujuk kepada tugas dan tanggung jawab selain syari'ah dan ajaran Islam secara umum. Sedangkan adab merujuk kepada sikap yang dihubungkan dengan tingkah laku yang baik. Sebagai usaha yang identik dengan ajaran agama, pendidikan karakter dalam Islam memiliki keunikan dan perbedaan dengan pendidikan karakter di dunia Barat. Perbedaan tersebut mencakup penekanan terhadap prinsip-prinsip agama yang abadi, aturan dan hukum dalam memperkuat moralitas, perbedaan pemahaman tentang kebenaran, penolakan terhadap otonomi moral sebagai tujuan pendidikan moral. Inti dari perbedaan-perbedaan ini adalah keberadaan wahyu Ilahi sebagai sumber dan rambu-rambu pendidikan karakter dalam Islam. Akibatnya, pendidikan karakter dalam Islamlebih sering dilakukan secara doktriner dan dogmatis, tidak secara demokratis dan logis.

Pendidikan karakter seharusnya berangkat dari konsep dasar manusia, yakni fitrah. Setiap anak dilahirkan menurut fitrahnya, yaitu memiliki akal, nafsu (jasad), hati dan ruh. Konsep inilah yang sekarang lantas dikembangkan menjadi konsep multiple intelligence. Dalam Islam terdapat beberapa istilah yang sangat tepat digunakan sebagai pendekatan pembelajaran, antara lain: tilâwah, ta'lîm', tarbiyah, ta'dîh, tazkiyah dan tadlrîb Tilâwah menyangkut kemampuan membaca; ta'lim terkait dengan pengembangan kecerdasan intelektual (intellectual quotient); tarbiyah menyangkut kepedulian dan kasih sayang secara naluriah yang didalamnya ada asah, asih dan asuh; ta'dîb terkait dengan pengembangan kecerdasan emosional (emotional quotient); tazkiyah terkait dengan pengembangan kecerdasan spiritual (spiritual quotient); dan tadlrib terkait dengan kecerdasan fisik atau keterampilan (physical quotient atau adversity quotient). (Ramayulis, 2008:14-18).

Pendidikan karakter sesungguhnya bukan sekedar hubungan horizontal antara individu dan individu yang lain, tetapi antara individu memiliki hubungan vertikal dengan Allah yang dipercaya dan diimani. Menurut Marzuki (t.t.:8), dalam al-Quran ditemukan banyak sekali pokok-pokok keutamaan karakter atau akhlak yang dapat digunakan untuk membedakan perilaku seorang Muslim, seperti perintah berbuat kebaikan (ihsan) dan kebajikan (al-birr), menepati janji (al-wafa), sabar, jujur, takut pada Allah SWT, bersedekah di jalan Allah, berbuat adil, dan pemaaf (QS. al-Qashash [28]: 77; QS. alBaqarah [2]: 177; QS. al-Muminun (23): 1-11; QS. al-Nur [24]: 37; QS. al-Furqan [25]: 35-37; QS. 
al-Fath [48]: 39; dan QS. Ali 'Imran [3]: 134). Ayat-ayat ini merupakan ketentuan yang mewajibkan pada setiap Muslim melaksanakan nilai karakter mulia dalam berbagai aktivitasnya.Thomas Lickona sebagai Bapak Pendidikan Karakter di Amerika pun mengisyaratkan adanya keterkaitan erat antar karakter dan spiritual (dalam Zubaedi,2012:65).

Dengan demikian, bila sejauh ini pendidikan karakter telah berhasil dirumuskan oleh para penggiatnya sampai pada tahapan yang sangat operasional yang meliputi metode, strategi dan teknik, sedangkan pendidikan akhlak syarat dengan informasi kriteria ideal dan sumber karakter baik, maka dari itu jika keduanya dipadukan akan sempurna dalam pembentukan karakter manusia. Hal ini sekaligus dapat menjadi nilai plus bahwa karakter memiliki ikatan yang kuat dengan nilai-nilai spiritualitas dan agama.

Dalam al-Quran, manusia adalah makhluk dengan berbagai karakter. Dalam kerangka besar manusia mempunyai dua karakter yang saling berlawanan, yaitu karakter baik dan buruk. Sebagaimana firman Allah dalam QS.Asy-Syams [91]: 8-10.

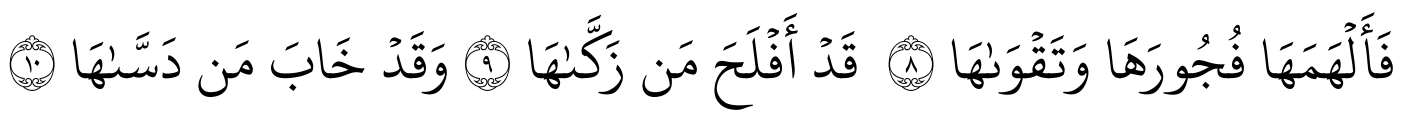

Artinya: "Maka Allah mengilhamkan kepada jiwa itu (jalan) kefasikan dan ketakwaannya. Sesungguhnya beruntunglab orang yang mensucikan jiwwa itu. Dan Sesunggubnya merugilah orang yang mengotorinya".

Karakter dapat diartikan juga dengan nilai-nilai perilaku manusia yang berhubungan dengan Tuhan Yang Maha Esa, diri sendiri, sesama manusia, lingkungan dan kebangsaan yang terwujud dalam pikiran, sikap, perasaan, perkataan dan perbuatan yang berlandaskan norma-norma agama, hukum, tata karma, budaya dan adat istiadat yang berlaku di lingkungannya. Nilai-nilai tersebut dirumuskan oleh Kemendiknas (2010), sebagai berikut:

1. Nilai religius; yaitu sikap dan perilaku yang patuh dalam melaksanakan ajaran agama yang dianutnya, toleran terhadap pelaksanaan ibadah agama lain, dan hidup rukun dengan pemeluk agama lain.

2. Nilai jujur; yaitu perilaku yang didasarkan pada upaya menjadikan dirinya sebagai orang yang selalu dapat dipercaya dalam perkataan, tindakan, dan pekerjaan.

3. Nilaitoleransi; yaitu sikap dan tindakan yang menghargai perbedaan agama, suku, etnis, pendapat, sikap, dan tindakan orang lain yang berbeda dari dirinya.

4. Nilaidisiplin; yaitu tindakan yang menunjukkan perilaku tertib dan patuh pada berbagai ketentuan dan peraturan.

5. Nilai kerja keras; yaitu tindakan yang menunjukkan perilaku tertib dan patuh pada berbagai ketentuan dan peraturan.

6. Nilai kreatif; yaitu berpikir dan melakukan sesuatu untuk menghasilkan cara atau hasil baru dari sesuatu yang telah dimiliki.

7. Nilai mandiri; yaitu sikap dan perilaku yang tidak mudah tergantung pada orang lain dalam menyelesaikan tugas-tugas.

8. Nilai demokratis; yaitu cara berfikir, bersikap, dan bertindak yang menilai sama hak dan kewajiban dirinya dan orang lain.

9. Nilai rasa ingin tahu; yaitu sikap dan tindakan yang selalu berupaya untuk mengetahui lebih mendalam dan meluas dari sesuatu yang dipelajarinya, dilihat, dan didengar. 
10. Nilai semangat kebangsaan; yaitucara berpikir, bertindak, dan berwawasan yang menempatkan kepentingan bangsa dan negara di atas kepentingan diri dan kelompoknya.

11. Nilai cinta tanah air; yaitu cara berpikir, bertindak, dan berwawasan yang menempatkan kepentingan bangsa dan negara di atas kepentingan diri dan kelompoknya.

12. Nilai menghargai prestasi; yaitu sikap dan tindakan yang mendorong dirinya untuk menghasilkan sesuatu yang berguna bagi masyarakat, dan mengakui, serta menghormati keberhasilan orang lain.

13. Nilai berrsahabat/komunikatif; yaitu sikap dan tindakan yang mendorong dirinya untuk menghasilkan sesuatu yang berguna bagi masyarakat, dan mengakui, serta menghormati keberhasilan orang lain.

14. Nilai cinta damai; yaitusikap dan tindakan yang mendorong dirinya untuk menghasilkan sesuatu yang berguna bagi masyarakat, dan mengakui, serta menghormati keberhasilan orang lain.

15. Nilai gemar membaca; yaitukebiasaan menyediakan waktu untuk membaca berbagai bacaan yang memberikan kebajikan bagi dirinya.

16. Nilai peduli lingkungan; yaitusikap dan tindakan yang selalu berupaya mencegah kerusakan pada lingkungan alam di sekitarnya, dan mengembangkan upaya-upaya untuk memperbaiki kerusakan alam yang sudah terjadi.

17. Nilai peduli sosial; yaitusikap dan tindakan yang selalu ingin memberi bantuan pada orang lain dan masyarakat yang membutuhkan.

18. Nilai tanggung jawab; yaitusikap dan perilaku seseorang untuk melaksanakan tugas dan kewajibannya, yang seharusnya dia lakukan, terhadap diri sendiri, masyarakat, lingkungan (alam, sosial dan budaya), negara dan Tuhan Yang Maha Esa. (wmw.perpustakaan.kemdiknas.go.id).

Berdasarkan uraian tersebut, maka pijakan utama yang harus dijadikan sebagai landasan dalam menerapkan pendidikan karakter ialah nilai moral universal yang dapat digali dari agama. Meskipun demikian, ada beberapa nilai karakter dasar yang telah disepakati para pakar untuk diajarkan kepada peserta didik yakni rasa cinta kepada Tuhan Yang Maha Esa dan ciptaan-Nya, jujur, tanggungjawab, hormat, santun, kasih sayang, mampu bekerjasama, percaya diri, kreatif, mau bekerja keras, pantang menyerah, adil, serta memiliki sifat kepemimpinan, baik dan rendah hati, toleransi, cinta damai dan cinta persatuan.

\section{Mendidik Karakter pada Anak}

Anak merupakan bagian dari generasi muda sebagai salah satu sumber daya manusia yang memiliki peranan strategis dalam pembentukan sebuah keluarga menjadi lebih baik, sehingga memerlukan pembinaan dan perlindungan dalam rangka menjamin pertumbuhan dan perkembangan anak, baik fisik, psikis, mental serta sosial anak. Oleh karena itu, perlu adanya perhatian yang cukup besar dari sebuah keluarga terhadap anak yang mampu memikul tanggung jawab untuk sebuah keluarga dan anak yang masih memerlukan tanggung jawab dari keluarganya.

Dalam pendefenisianterm anak, terdapat relatifitas yang sangat besar dalam mengartikan seorang anak, karena pendefenisian ini akan menentukan batasan, baik berupa batasan umur atau batasan lain yang nantinya akan berpengaruh terhadap hak dan tangggung jawab (beban hukum) yang dipikul anak dalam sebuah keluarga.

Imam Al-Ghazali mengungkapkan bahwa anak itu terbagi pada 4 (empat) masa yaitu:

1. "al-janin" yaitu tingkat anak yang berada dalam kandungan.

2. "al-thifl" yaitu tingkat anak-anak dengan memperbanyak latihan sehingga mengetahui baik buruk. 
3. "al-tamyiz" yaitu tingkat anak yang telah membedakan sesuatu yang baik dan yang buruk, bahkan akal pikirannya telah berkembang.

4. "al-aqil" yaitu tingkat manusia yang telah berakal sempurna. Dari keempat penggolongan ini, maka batasan seseorang bisa dikatakan anak adalah hingga mencapai tahap "al-aqil", artinya anak telah bisa dan dapat dibebani hukum. (dalam Zainuddin, 1991:69).

Tidak jauh berbeda dengan penggolongan yang dilakukan Al-Ghazali, Syaikh Khalid Abdurrahman (2010:7-8)mendefenisikan anak sebagai seseorang yang berumur 18 (delapan belas) tahun ke bawah. Dia mengklasifikasikan anak pada empat tahap, yaitu: pertama, tahap sebelum lahir. Kedua, tahap masa kanak-kanak pertama, tahap ini dimulai dari awal mula pengasuhan hingga usia 7 (tujuh) tahun.Ketiga, tahap masa kanak-kanak kedua, yaitu dimulai dari umur 7 (tujuh) tahun hingga berumur 12 (dua belas) tahun. Keempat, yaitu tahap pubertas yang dimulai dari usia 12 (dua belas) tahun hingga usia 18 (delapan belas) tahun. Penggolongan anak tersebut berakhir pada usia delapan belas tahun yang telah cakap hukum (telah mampu memikul tanggung jawab).

Sedangkan jika dilihat dari segi psikis (psikologies), menurut Y. Byl, anak adalah keturunan hingga umur delapan belas tahun atau disebut dengan masa pubertas, pada masa ini anak sudah bisa menentukan pilihan yang terbaik untuk dirinya. (dalam Abu Ahmadi dan Widodo Supriyono 2004:47).

Berdasarkan pengertian anak tersebut, maka pengembangan nilai-nilai budaya dan karakter bangsa anak usia dini harus dilakukan dengan tepat. Jika hal ini tidak bisa tercapai, pesan moral yang akan disampaikan orangtua dan pendidik kepada anak menjadi terhambat. Pengembangan nilai moral untuk anak usia dini bisa dilakukan di dalam tiga tri pusat pendidikan yang ada, yaitu, keluarga, sekolah, dan masyarakat. Dalam pengembangan nilai moral untuk anak usia dini perlu dilakukan dengan sangat hati-hati. Hal ini dikarenakan anak usia dini adalah anak yang sedang dalam tahap perkembangan praoperasional konkret seperti yang dikemukakan oleh Piaget. Sedangkan nilai-nilai moral merupakan konsep-konsep yang abstrak. Sehingga dalam hal ini anak belum bisa dengan serta-merta menerima apa yang diajarkan guru atau orangtua yang sifatnya abstrak secara cepat. Untuk itulah orangtua dan pendidik harus pandai-pandai dalam memilih dan menentukan metode yang akan digunakan untuk menanamkan nilai moral kepada anak agar pesan moral yang ingin disampaikan guru dapat benarbenar sampai dan dipahami oleh anak untuk bekal kehidupannya di masa depan. Berdasarkan pengertian tersebut, maka dalam mendidik karakter anak tentu memiliki pendekatan yang berbeda dalam setiap individu. Dalam hal ini diperlukan metodeyang digunakan dalam upaya mendidik karakter anak. Oleh itu, menurut Abdullah Nashih Ulwan (2013:363) terdapat beberapa metode dalam upaya pembentukan pendidikan karakter peserta didik, antara lain:

\section{Keteladanan}

Keteladanan dalam proses pendidikan adalah sebuah metode inflentif yakni menekankan keberhasilan dalam mempersiapkan nilai moral, spritual dan sosial anak. Dalam hal ini menjadi sasarannya karena pendidikan adalah contoh terbaik dalam pandangan anak yang akan ditirunya, dalam tindak-tanduk dan tata santunnya, disadari atau tidak, bahkan tercetak dalam jiwa dan perasaan suatu gambaran pendidikan tersebut, baik material atau spritual, diketahui atau tidak diketahui.

2. Latihan dan Pembiasaan

Tujuan utama pembiasaan adalah menanamkan kecakapan-kecakapan berbuat dan mengucapkan sesuatu agar cara-cara yang tepat dapat dikuasai anak. Oleh karena itu, pembiasaan menjadi salah satu aspek dalam pembentukan kepribadian anak. Pendidikan agama melalui pembiasaan 
dan latihan seperti sopan santun, dan pola tingkah laku yang sesuai dengan petunjuk agama harus dicontohkan kepada anak.

\section{Pemberian Nasehat}

Nasehat mempunyai dua makna yakni nasehat berarti sajian bahasa tentang kebenaran dan maksud mengajarkan orang yang dinasehati untuk mengamalkannya. Selanjutnya nasehat juga berarti peringatan yang bermakna memberikan nasehat hendaklah berulang agar yang dinasehati tergugah untuk mengerjakannya. Dengan demikian, hendaklah nasehat yang disampaikan dengan ikhlas dan berulang-ulang agar nasehat itu mendapat perhatian dari yang menerima nasehat.

\section{Memberikan Hukuman}

Masalah boleh menghukum atau tidak boleh menghukum anak adalah suatu masalah yang rumit dalam dunia pendidikan. Prof. Konstam, seorang tokoh pendidikan Belanda sebagaimana yang dikutip Suryani, berpendapat bahwa pentingnya hukuman dalam dunia pendidikan adalah untuk membentuk watak yang diperlukan untuk pendidikan. Dan bila anak menyadari kesalahannya, maka pendidik dan orangtua wajib mengampuninya.

\section{Hukum Islam dan Pembangunan Karakter}

Pada dasarnya kata "hukum Islam" sama sekali tidak ditemukan baik dalam Al-Qur'an ataupun dalam literatur fikih Islam. Yang ada dalam Al-Qur'an adalah kata syariah, fikih, bukm Allah dan yang seakar dengannya. Namun menurut Amir, secara sederhana dapat dikatakan bahwa hukum Islam adalah hukum yang berdasarkan wahyu Allah. Dengan demikian hukum Islam menurut ta'rif ini mencakup syari'at (hukum yang abadi dan qath'i) dan juga mencakup fikih (hukum yang zhanni dan ijtibadi), karena arti syara' dan fikih terkandung didalamnya (Amir, 1990:18-19).

Secara umum sering dirumuskan bahwa tujuan hukum Islam adalah kebahagiaan hidup manusia di dunia ini dan di akhirat kelak, dengan jalan mengambil (segala) yang bermanfaat dan mencegah atau menolak yang mudarat yaitu yang tidak berguna bagi hidup dan kehidupan. Dengan kata lain, tujuan hukum Islam adalah kemaslahatan hidup manusia, baik rohani maupun jasmani, individual maupun sosial. Kemaslahatan itu tidak hanya untuk kehidupan di dunia ini saja tetapi juga untuk kehidupan yang kekal di akhirat kelak. Abu Ishaq al Shatibi (m.d. 790/1388) merumuskan lima tujuan hukum Islam, yakni memelihara agama (ad-din), jiwa (al-nafs), keluarga (al-nas), akal (al-aql), dan harta (al-mal), yang (kemudian) disepakati oleh ilmuan hukum Islam lainnya. Kelima tujuan hukum Islam itu didalam kepustakaan di sebut al-maqasid al-khamsah atau al-maqasid al-shari'ah (tujuan-tujuan hukum Islam). (Daud Ali, 1999:54).

Para ulama ushul telah mengumpulkan maksud-maksud syara' yang umum dari mentasyri'kan hukum (tujuan-tujuan dalam hukum Islam) dalam tiga maksud pokok, yaitu:

a. Maksud yang pertama: memelihara segala yang dlaruri bagi manusia dalam penghidupan mereka. Urusan-urusan yang dlaruri itu, ialah: segala yang diperlukan untuk hidup manusia yang asasi atau sangat pokok, yang apabila dia tidak terdapat, cederalah undang-undang kehidupan, timbullah kekacauan dan berkembang biaklah kerusakan.

b. Maksud yang kedua: menyempurnakan segala yang dihajati manusia.

Urusan-urusan yang dihajati dalam pengertian ini, melengkapi segala yang menolak kepicikan, meringankan kesukaran taklif dan memudahkan jalan-jalan bermu'amalah.

c. Maksud yang ketiga: mewujudkan keindahan bagi perseorangan dan masyarakat. 
Yang dikehendaki dengan urusan-urusan yang mengindahkan, ialah: segala yang diperlukan oleh rasa kemanusiaan, kesusilaan dan keseragaman hidup. Apabila yang demikian ini tiada diperoleh, tiadalah cedera peraturan hidup dan tiada pula ditimpa kepicikan. Hanya dipandang tidak baik oleh aqal yang kuat dan fithrah yang sejahtera.

Urusan-urusan yang mengindahkan ini, dalam arti begini, kembali kepada soal akhlak dan adat istiadat yang bagus dan segala yang dimaksudkan untuk mencapai keseragaman hidup melalui jalan-jalan yang utama. (Ash-Shiddieqy, 1981:81).

Hukum Islam idealnya di ajarkan pada anak sejak menginjak usia tamyiz, khususnya yang berkaitan dengan kecenderungan naluri dan kematangan seksualnya (Ulwan, 2013:326). Begitu banyak anak yang selama bertahun-tahun tidak suci karena mereka tidak tahu hukum-hukum yang harus dilaksanakan ketika junub, menstruasi (haidh), dan mimpi basah bagi laki-laki. Boleh jadi anak akan tetap melaksanakan shalat karena menganggap telah melaksanakan hak Allah berupa ketaatan dan ibadah. Padahal ketika anak laki-laki mencapai usia remaja antara 12-15 tahun, apabila ia sudah keluar air mani (sperma) yang menyembur dengan syahwat, berarti ia telah baligh dan mendapat beban hukum syar'i (mukallaf). Ia juga diwajibkan menjalankan semua kewajiban para lelaki dewasa, berupa berbagai tanggung jawab dan beban hukum. Begitu pula dengan anak perempuan.

Dalam hal ini, hukum Islam memiliki hubungan yang erat dan tidak dapat dipisahkan dari iman atau akidah dan kesusilaan atau akhlak Islam.Karakteristiknya dapat di bagi menjadi (a) hukum taklifi yakni al-abkam al-khamsah yaitu lima jenis kaidah yang disebut al abkam al khamsah atau penggolongan hukum yang lima, yaitu (1) wajib, (2) sunnat, (3) baram, (4) makrub dan, (5) ja’izatau mubah atau ibahab; dan (b) hukum wadh'i yang mengandung sebab, syarat, halangan terjadi atau terwujudnya hubungan hukum. (Daud Ali, 39-52).

Pergolongan hukum yang lima di dalam kepustakaan hukum Islam disebut juga bukum taklifi yakni norma atau kaidah hukum Islam yang mungkin mengandung kewenangan terbuka yaitu kebebasan memilih untuk melakukan atau tidak melakukan sesuatu perbuatan, yang disebut ja'iz, mubah atau ibahah. Mungkin juga bukum taklifi itu mengandung anjuran untuk dilakukan karena jelas manfaatnya bagi pelaku (sunnat). Mungkin juga mengandung kaidah yang seyogyanya tidak dilakukan karena jelas tidak berguna dan akan merugikan orang yang melakukannya (makrub). Mungkin juga mengandung perintah yang wajib dilakukan (fardu atau wajib), dan mengandung larangan untuk dilakukan (haram).

Dalam ungkapan yang lain, Yusuf Al-Qaradhawi menyatakan: "di mana ada kemaslahatan, di sanalah terdapat bukum Allah." (Qaradhawi, 1998:68). Senada dengan al-Qaradhawi, Masdar Farid Mas'udi juga menempatkan kemaslahatan dan keadilan sebagai landasan syari'at, baik landasan filosofis maupun epsitemologinya. Masdar berpendapat bahwa hukum haruslah didasarkan kepada sesuatu yang tidak disebut hukum, akan tetapi didasarkan kepada yang lebih mendasar dari sekedar hukum, yaitu sebuah sistem nilai yang dengan sadar diambil sebagai sebuah keyakinan yang harus diperjuangkan, yakni kemaslahatan (good interest) dan keadilan (justice). Hal ini senada dengan pendapat C.A. Van Peursen bahwa filsafat harus membahas masalah-masalah aktual, faktual kontekstual bukan hanya yang abstrak tekstual.(Peursen, 1998:22).

Maka dalam proses perkembangan dan pembentukannya, karakter seseorang dipengaruhi oleh dua faktor, yaitu faktor lingkungan (nurture) dan faktor bawaan (nature). Secara psikologis perilaku berkarakter merupakan perwujudan dari potensiIntelligence Quotient (IQ), Emotional Quotient (EQ), Spiritual Quotient (SQ), dan Adverse Quotient (AQ) yang dimiliki oleh seseorang. Konfigurasi karakter dalam konteks totalitas proses psikologis dan sosio-kultural pada akhirnya dapat dikelompokkan dalam empat kategori, yakni (1) olah hati (spiritual and emotionaldevelopment), (2) olah 
pikir (intellectual development), (3) olah raga dan kinestetik (physical and kinestetic development), dan (4) olah rasa dan karsa (affective andcreativity development). Keempat proses psiko-sosial ini secara holistik dan koheren saling terkait dan saling melengkapi dalam rangka pembentukan karakter dan perwujudan nilai-nilai luhur dalam diri seseorang (Kemendiknas, 2010: 9-10).

Pendidikan karakter bukan hanya sekadar menanamkan mana yang benar dan salah. Pendidikan karakter merupakan usaha menanamkan kebiasaan-kebiasaan yang baik (babituation). Sehingga anak mampu bersikap dan bertindak berdasarkan nilai-nilai yang telah menjadi kepribadiannya, harus melibatkan pengetahuan yang baik (moralknowing), perasaan yang baik atau loving good (moralfeeling) dan perilaku yang baik (moralaction), sehingga terbentuk perwujudan kesatuan perilaku dan sikap hidup anak.

\section{Tripusat Pendidikan dan Karakter Anak: Penguatan Pendidikan Agama dan Pengenalan Hukum Islam}

Dalam berbagai tinjauan, keluarga adalah tempat pendidikan pertama dan utama bagi anakanak. Orangtua merupakan salah satu elemen penting dalam menanamkan pendidikan karakter pada anak. Karakter tentu berbeda dengan pendidikan moral, karena memerlukan pembiasaan.Karena kontinuitas inilah yang membentuk karakter secara permanen dan tahan lama. Teori-teori pendidikan pun bermunculan. Teori yang mengatakan bahwa perkembangan anak ditentukan oleh faktor lingkungan yang dipelopori oleh Jhon Locke yang dikenal sebagai teori Empirisme, Teori yang mengatakan bahwa perkembangan anak ditentukan oleh faktor hereditas atau pembawaan yang dipelopori oleh Arthur Schopen Hauer yang dikenal sebagi teori Nativisme, dan banyak lagi teori-teori yang mengemukakan perkembangan seorang anak serta faktor-faktornya. (Achmadi dan Supriyono, 2004).

Padahal apabila kita cermati, semua faktor-faktor tersebut saling berkaitan dan mempengaruhi satu sama lain, dari mulai keluarga, pembawaan serta lingkungan dimana anak itu tinggal. Apabila kita melihat dari pendidikan Islam untuk anak, sebenarnya kita bisa melatih karakter anak-anak itu pada kegiatan sehari-harinya sesuai dengan anjuran dan kebiasaan Nabi Muhammad SAW.

Karakter seorang anak terbentuk dari kebiasaannya sehari-hari. Menurut Gilbert Highest (1961:78) dalam Psikologi Agama (Jalaludin, 2010:291), kebiasaan yang dimiliki anak-anak sebagian besar terbentuk oleh pendidikan keluarga. Adapun potensi yang dimiliki seorang bayi menurut Walter Houston Clark (1964) ada dua aspek yang kontradiktif. Di satu sisi bayi yang baru lahir berkondisi tanpa daya, di sisi lain bayi memiliki kemampuan untuk berkembang (eksploratif). Perkembangan bayi tak akan berkembang secara normal tanpa adanya intervensi dari luar, walaupun secara alami ia memiliki potensi bawaan. Allah SWT berfirman:

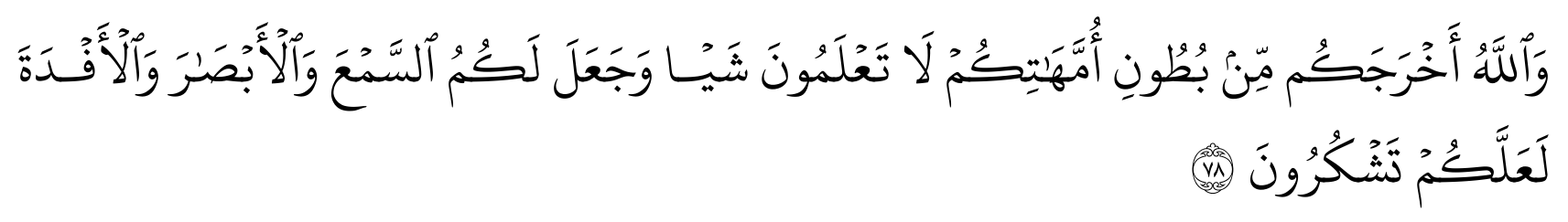

"Dan Allah mengeluarkan kamu dari perut ibumu dalam keadaan tidak mengetabui sesuatupun, dan dia memberi kamu pendengaran, penglihatan dan hati, agar kamu bersyukur.” (QS. An-Nahl [16]:78) 
Orangtua juga berkewajiban memberikan pendidikan agama kepada anaknya dalam upaya menyelamatkan mereka dari siksa api neraka. Allah SWT berfirman:

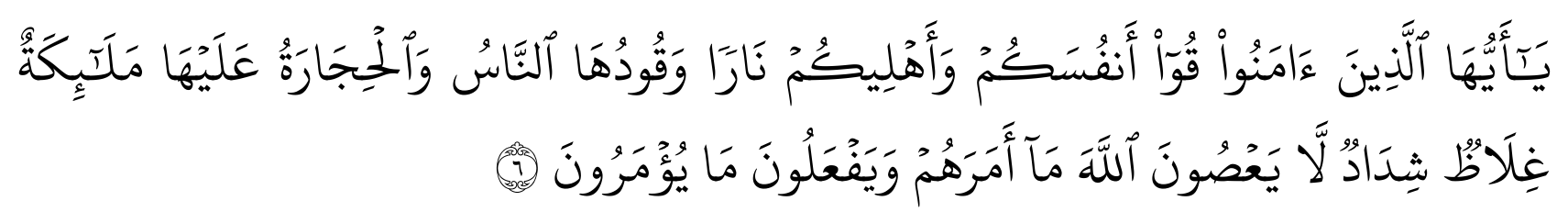

"Hai orang-orang yang beriman, peliharalah dirimu dan keluargamu dari api neraka yang bahan bakarmya adalah manusia dan batu; penjaganya malaikat-malaikat yang kasar, keras, dan tidak mendurbakai Allah terhadap apa yang diperintabkan-Nya kepada mereka dan selalu mengerjakan apa yang diperintabkan "(QS. At-Tahrim [66]: 6)

Pendidikan keluarga adalah benteng utama tempat anak-anak dibesarkan melalui pendidikan dan di sinilah peran utama orangtua sebagai pendidik yang akan mendasari dan mengarahkan anakanaknya pada pendidikan selanjutya. Tanggung-jawab pendidikan keluarga ada di pundak para orangtua, sehingga anak-anak terhindar dari kerugian, keburukan, mengingat banyaknya sendi kehidupan sosial yang melenceng dari tujuan pendidikan. Maka hal yang perlu diajarkan pada anak, antara lain:

1. Mengajarkan Tauhid Aqidah Kepada Anak

Tauhid adalah merupakan hal yang penting untuk diketahui oleh anak-anak kita ketika sudah mulai belajar mengenal akan agama islam ini. Suatu hal yang tidak bisa dipungkiri bahwa tauhid merupakan landasan Islam. Apabila seseorang benar tauhidnya, maka dia akan mendapatkan keselamatan di dunia dan akhirat. Sebaliknya, tanpa tauhid dia pasti terjatuh ke dalam kesyirikan dan akan menemui kecelakaan di dunia serta kekekalan di dalam adzab neraka.

Mengajarkan akan hal ini dimulai dari hal yang kecil, yaitu mengenal Allah sebagai Tuhan kita Umat Islam, Muhammad SAW adalah Rasul Nabi kita. Tentunya hal ini disesuaikan dengan tahapan umur anak, disesuaikan dengan pemahaman seorang anak. Dimulai dari contoh orangtua dalam menjalankan sholat 5 waktu, berdoa ketika akan makan, dan segala aktifitas dimulai dan diakhiri dengan berdoa sesuai dengan contoh-contoh doa yang Rasulullah SAW ajarkan kepada kita semua dalam hadist-hadist yang sohih.

2. Mengajarkan Memberikan Contoh Menunaikan Ibadah Sesuai Syari'ah Islam

Mengajarkan memang hal yang mudah, akan tetapi memberikan keteladanan contoh itulah yang kadangkala dilupakan oleh para orangtua. Justru seorang anak ketika mengetahui akan berbagai macam ibadah baik yang wajib maupun yang sunnah akan tetapi tidak pernah melihat orangtuanya melakukannya di rumah tentunya akan hanya membekas dalam pikirannya akan tetapi tidak membekas di dalam hatinya.

Anak ibarat kertas putih, yang bisa ditulis dengan tulisan apa saja. Peran orangtua sangatlah vital. Karena melalui orangtualah, anak akan menjadi manusia yang baik atau tidak. Rasulullah SAW, sebagai teladan paripurna, telah memberikan tuntunan bagaimana mendidik dan mempersiapkan anak.

Dan hal yang paling penting adalah keteladanan dalam melakukan hal-hal yang utama. Inilah yang harus dilakukan orangtua. Bukan hanya memerintah dan menyalahkan, tapi yang lebih penting 
adalah memberikan contoh kongkret. Secara simultan hal itu juga harus ditopang oleh lingkungan, pergaulan, dan masyarakat.

3. Mengajarkan Al-Quran, Hadits serta Doa dan Dzikir yang Ringan kepada Anak-anak

Dimulai dengan surat Al-Fathihah dan surat-surat yang pendek serta doa tahiyat untuk shalat. Dan menyediakan guru khusus bagi mereka yang mengajari tajwid, menghapal Al-Quran serta hadits.

Begitu pula dengan doa dan diikir sehari-hari. Hendaknya mereka mulai menghapalkannya, seperti doa ketika makan, keluar masuk WC dan lain-lain.

4. Mendidik Anak dengan Berbagai Adab dan Akhlaq yang Mulia

Mengajari kepada anak-anak tentang berbagai macam adab Islami seperti makan dengan tangan kanan, mengucapkan basmalah sebelum makan, menjaga kebersihan, mengucapkan salam, dan lain-lain.

Begitu pula dengan akhlak. Tanamkan kepada mereka akhlaq-akhlaq mulia seperti berkata dan bersikap jujur, berbakti kepada orangtua, dermawan, menghormati yang lebih tua dan sayang kepada yang lebih muda, serta beragam akhlaq lainnya.

Dan juga kenalkan akan adab terhadap makhluk hidup lainnya. Adab dan akhlak terhadap hewan dan tumbuhan yang sesuai dengan tuntunan syari'at, seperti tidak menyakitinya, tidak menyiksanya, memberinya makan dan minum, merawatnya, dan tidak membunuhnya dengan caracara yang dilarang oleh agama.

Penguatan landasan pendidikan anak tentu harus diawali dengan kewajiban menumbuhkan sejak dini kecintaan terhadap Allah dan Rasul-Nya serta mencintai ajaran Islam. Hendaknya pula dikabarkan bahwa Allah memiliki neraka dan surga. Neraka Allah sangat panas, bahan bakarnya dari manusia dan batu.Sebagaimana yang dicontohkan oleh Nabi Muhammad SAW, di mana kecilnya usia Abdullah bin Abbas tidak mengalangi Rasulullah SAW untuk menyampaikan kepadanya ajaran-ajaran tauhid dan aqidah. Dari Ibnu Abbas, dia berkata, "Aku dahulu suatu hari berada di belakang Rasulullah shallallahu alaihi wa sallam, lalu beliau berkata, "Wahai ananda, aku ajarkan kepadamu beberapa pelajaran; Jagalah Allah, Dia akan menjaga-Mu. Jagalah Allah, engkau akan dapatkan Dia berada di hadapan-Mu. Jika engkau meminta, maka mintalah kepada Allah. Jika engkau minta pertolongan, maka mintalah pertolongan kepada Allah. Ketahuilah, sesunggubnya umat ini, jika mereka berkumpul untuk mendatangkan suatu manfaat untukmu, niscaya mereka tidak dapat mendapatkan manfaat untukmu kecuali apa yang Allah tetapkan untukmu. Dan seandainya mereka berkumpul untuk mendatangkan bahaya untukmu, niscaya mereka tidak dapat mendatangkan suatupun bahwa untukmu selain apa yang telah Allah tetapkan untukemu. Qalam telah diangkat dan catatan telah kering." (HR. Tirmizi, no. 2516, dinyatakan shahih oleh Al-Albany dalam Shahih Tirmizi).

Selanjutnya, menjauhkan anak dari tempat-tempat keburukan dan kelalaian. Jangan biarkan mereka didik dengan cara yang buruk, baik melalui televisi atau selainnya dan kemudian anda mengharapkan kesalehannya. Orang yang menanam duri tidak akan memanen anggur. Hendaknya pendidikan tersebut telah ditanam sejak kecil agar mudah baginya ketika dia sudah besar untuk memerintah dan melarangnya, dan mudah baginya untuk mentaati anda. Sebagaimana sabda Nabi SAW, dari Abdullah bin Amr bin Ash radhiallahu anhuma, dia berkata, Rasulullah shallallah alaihi wa sallam bersabda, "Perintabkan anak kalian untuk melakukan shalat saat mereka berusia tujuh tahun, dan pukullah mereka apabila berusia sepulub tabun, lalu pisabkan ranjang di antara mereka."(HR. Abu Daud, no. 495, dishahihkan oleh Al-Albany dalam Shahih Al-Jami, no. 5868)

Akan tetapi hendaknya bagi pendidik untuk bersikap lembut dan santun, memudahkan dan akrab, tidak berkata kasar, berlaku keras dan mendiskusikan dengan cara yang baik. Hindari celaan dan caci maki hingga pukulan. Kecuali jika sang anak durhaka dan menganggap remeh perintah bapaknya, 
meninggalkan perkara yang diwajibkan dan melakukan perkara yang diharamkan. Ketika itu diutamakan bersikap namun tidak sampai menimbulkan bahaya.Al-Manawi berkata," Seseorang yang mendidik anaknya ketika dia berusia baligh dan telah berakal dengan pendidikan yang dapat mengantarkannya pada akblak orang-orang saleh dan melindunginya agar tidak bergaul dengan orang-orang rusak, kemudian mengajarkannya Al-Quran, adab, bahasa Arab, kemudian dia memperdengarkan sang anak. kisah-kisah dan ucapan para salaf, lalu mengajarkannya ajaran agama yang tidak boleb ditinggalkan, kemudian dia mengancam memukulnya apabila sang anak tidak shalat, semua itu lebih baik baginya daripada dia bersadaqah satu sha'. Karena jika dia mendidiknya, maka perbuatannya termasuk shadaqah jariyah, sementara sadaqah satu sha', pabalanya akan terputus. Sementara yang pertama tetap terus mengalir selama sang anak masih ada. Dan adab adalah makanan jiwa dan pendidikannya untuk akbirat kelak 'Jagalah diri kamu semua dan keluargamu dari api neraka.' QS. AtTabrim: 6."

Adapun dari sisi pengenalan hukum Islam, anak perlu diberi pemahaman sederhana minimal mengenai hukum halal dan haram, terpuji dan tercelanya suatu perbuatan. Syari'ah telah menetapkan peraturan sanksi dalam Islam, dan hal itu banyak dalam Islam, seperti hukum zina, mencuri, menuduh berzina (tanpa bukti) dan sebagainya. Semuanya itu disyari'ahkan agar manusia istiqamah dan menghindari perbuatan buruk.Dalam hal inilah Rasulullah SAW berpesan untuk mengajarkan seorang bapak agar anak menurutinya.Dari Ibnu Abbas, dari Rasulullah SAW bersabda,"Gantungkan pecut di tempat yang dapat dilihat keluarga, karena itu merupakan pendidik bagi mereka." (HR. Thabrani, 10/248). Hadits ini dinyatakan hasan oleh Al-Haitsami dalam Majma Zawaid (8/106) Al-Albany menyatakan dalam shahih Al-Jami, no. 4022, hadits ini hasan.

Pendidikan anak hendaknya berimbang antara anjuran dan peringatan. Yang lebih penting dari itu semua adalah memperbaiki lingkungan tempat anak tinggal dengan mewujudkan sebab-sebab hidayah bagi mereka, yaitu dengan komitmennya pendidik dan pengasuh mereka yang tak lain adalah kedua orangtua mereka.

Bagi anak usia dini, pengenalan hukum Islam bisa didik melalui akhlak atau etika bersosial yang baik menurut Islam. Saat dia merebut mainan temannya, ingatkan untuk meminjam secara baikbaik. Saat temannya berbagi mainan, ajarkan untuk berterima kasih. Saat dia melakukan kesalahan, ajarkan untuk meminta maaf. Ketiga konsep ini tidak saja harus diajarkan, tapi juga mesti dicontohkan oleh kedua orangtua. Bagaimanapun, keteladanan orangtua adalah guru terbaik bagi si kecil. Al Quran berulang kali menekankan betapa pentingnya keteladanan dalam menuju suksesnya pendidikan akhlak (QS 33:21; Al Mumtahanah 60:4, 6). Apa yang ingin dilakukan oleh anak, hendaknya dilakukan juga oleh orangtua. Apa yang tidak ingin dilakukan anak, hendaknya orangtua tidak melakukannya juga.Sebagai contoh, apabila sang ayah ingin anaknya tidak merokok, maka ia hendaknya juga tidak merokok; berhenti merokok apabila asalnya seorang perokok; atau setidak-tidaknya tidak merokok di depan anak-anaknya.

Disiplin harus dimulai dari usia ini. Menanamkan disiplin artinya memberi hukuman atas kesalahan yang dilakukan anak. Disiplin bertujuan agar supaya anak tahu bahawa apa yang dilakukan itu tidak baik. Ketika anak usia 4-5 tahun cenderung berfikir pendek. Oleh karena itu, orangtua harus menyadari bahwa satu kali penanaman disiplin untuk suatu kesalahan tidaklah cukup.Anak mungkin akan mengulangi kesalahan yang sama beberapa kali setelah itu. Orangtua tidak perlu terkejut atau putus asa. Yang terpenting adalah bahwa anak sudah mengambil pelajaran setiap kali menerima hukuman atas kesalahanannya. Pastikan orangtua tetap konsisten memberi sangsi disiplin setiap kali anak melakukan kesalahan. Baik kesalahan yang sama maupun kesalahan baru. Dan yang tak kalah penting, pastikan anak menerima pujian atau penghargaan setiap kali melakukan suatu hal yang baik. Apresiasi atau pujian pada anak usia ini antara lain berupa ucapan terima kasih sambil menyebutkan 
perbuatan baik apa yang telah dilakukan si anak. Misalnya, "Kamu telah merapikan mainanmu. Terima kasih.”.

Adapun hukuman pada anak jangan sampai yang bersifat fisikal, seperti memukul, menampar, mencubit, dsb. Hukuman fisik seperti itu akan sangat berbahaya bagi mental dan perilaku anak di kemudian hari. Hukuman disiplin hendaknya yang bersifat non-fisikal, seperti dikurung dalam kamar selama 5 menit, dan hukuman lainnya. Ketika anak sudah diajarkan kedisiplinan, lanjutkan dengan membangun karakter spiritual, di mana penekanan pendidikan keagamaan hendaknya diprioritaskan pada keharusan menyembah Allah dan tanda-tanda adanya Allah. Keesaan dan kekuasaan-Nya.

Jika kebiasaan salat lima waktu yang pada saat balita dilakukan tidak secara konsisten dan cuma satu atau dua waktu saja, maka pada usia ini orangtua hendaknya memberi pemahaman bahwa si anak harus mulai belajar untuk melakukan shalat lima waktu dalam sehari. Dan wajibnya melakukan salat tersebut. Hal ini agar anak siap secara mental saat dia diwajibkan melakukan salat lima waktu pada saat usianya mencapai 7 tahun. Rasulullah bersabda: "Perintabkanlab anak-anakmu sekalian shalat saat usia mereka tujub tabun dan pukullah mereka ketika sepulub tabun dan pisabkanlah mereka tempat tidurnya" (Hadits Riwayat Abu Daud).

Tentu saja, pola pikir dan pola sikap religius itu bukan hanya salat. Perlunya taat pada orangtua hendaknya juga menjadi etika prioritas yang selalu dicamkan ke hati anak dan didengungdengungkan di telinga anak dalam berbagai kesempatan sebagai salah satu bagian penting dari perilaku religius.Allah berfirman: "Dan hendaklah berbuat baik kepada ibu bapak. Jika salah seorang di antara keduanya atau kedua-duanya sampai berusia lanjut dalam pemelibaraanmu, maka sekali-kali janganlah engkau mengatakan pada keduanya perkataan 'ab' dan janganlah engkau membentak keduanya, dan ucapkanlah kepada keduanya perkataan yang baik (QS Al Isra' 17:23).

\section{PENUTUP}

Penanaman karakter pada anak sejak dini berarti ikut mempersiapkan generasi bangsa yang berkarakter, mereka adalahcalon generasi bangsa yang diharapkan mampu memimpin bangsa danmenjadikan negara yang berperadaban, menjunjung tinggi nilai-nilailuhur bangsa dengan akhlak dan budi pekerti yang baik serta menjadigenerasi yang berilmu pengetahuan tinggi dan menghiasi dirinyadengan iman dan taqwa. Indikator keberhasilan pendidikan karakter adalah jikaseseorang telah mengetahui sesuatu yang baik (knowing the good)(bersifat kognitif), kemudian mencintai yang baik (loving the good) (bersifat afektif), dan selanjutnya melakukan yang baik (acting thegood) (bersifat psikomotorik).

Pendidikan karakter bukanlah sekedar proses menghafal materi soal ujian dan memperoleh nilai baik, tetapi pendidikan karakter memerlukan pembiasaan. Pembiasaan untuk berbuat baik, pembiasaan untuk berlaku jujur, ksatria, malu berbuat curang, malu bersikap malas, malu membiarkan lingkungannya kotor. Karakter tidak terbentuk secara instan, tapi harus dilatih secara serius dan proporsional agar mencapai bentuk dan kekuatan yang ideal yakni yang utama adalah peran keluarga. Cara mengaplikasikan karakter yang utama adalah pendidikan agama, jika pendidikan agama telah diberikan kepada anak dengan baik maka dia akan mempunyai karakter yang mulia.

Melalui pertimbangan perkembangan anak yang dewasa belum pada waktunya, maka pengenalan terhadap hukum Islam kiranya perlu perlahan diajarkan, walaupun kewajibannya akan dibebankan setelah anak baligh. Bisa di mulai dengan etika bersosial yang baik menurut Islam, memberikan keteladanan dan contoh dari orangtua, peningkatan kedisiplinan, pemberian hukuman 
dan ganjaran, serta penguatan karakter spiritual. Pengenalan ini akan semakin membantu menguatkan karakter yang dimiliki anak, tentunya melalui pembiasaan.

Pendidikan karakter sebagai salah satu jalan untuk mengembalikan manusia pada kesadaran moralnya harus selalu dikawal oleh semua pihak, keluarga, lembaga pendidikan, media massa, masyarakat, dan pemerintah harus bahu membahu bekerjasama dalam tanggung jawab ini. Tanpa keterlibatan semua pihak, ideal-ideal dari dilakasanakannya pendidikan karakter hanya akan berakhir di tataran wacana dan gagasan. Oleh karena itu perlu program aksi secara menyeluruh dari semua komponen bangsa ini.

\section{REFERENSI}

Ahmadi, Abu. Supriyono, Widodo. 2004. Psikologi Belajar. Jakarta: Rineka Cipta.

Ali, Mohammad Daud. 1999. Hukum Islam: Pengantar Imu Hukum dan Tata Hukum Islam di Indonesia, Jakarta: PT Raja Grafindo Persada.

Amir,Sofan.dkk. 2011. Implementasi Pendidikan Karakter dalam Pembelajaran: Strategi Analisis dan Pengembangan Karakter Siswa dalam Proses Pembelajaran.Jakarta: Prestasi Pustakakarya.

Aunillah, Nur Isna, 2011. Panduan Menerapkan Pendidikan Karakter di Sekolah. Yogyakarta: Laksana.

Coon, Dennis. Introduction to Psychology: Gateways to Mind and Behavior. Edisi 12.Brock University, 2010.

Al-Ikk, Syaikh Khalid Abdurrahman.penj. Umar Burhanuddin. 2010. Pedoman Pendidikan Anak Menurut Al-Quran dan Sunnah. Surakarta: Al-Qowam.

Jalaludin. 2010. Psikologi Agama. Jakarta: Rajawali Press.

Kemendiknas. 2010. Pembinaan Pendidikan Karakter di Sekolab Menengah Pertama. Jakarta: Departemen Pendidikan Nasional.

Lickona, Thomas. 2012. Educating for Character Hoq Our School Can Teach Respect and Responsibility, diterjemahkan oleh Juma Abdu Wamaungo, dengan judul "Mendidik untuk Membentuk Karakter: Bagaimana Sekolah Dapat Memberikan Pendidikan Tentang Sikap Hormat dan Tanggung Jawab”. Jakarta: Bumi Aksara.

Marimba, Ahmad Daeng.1989. Pengantar Filsafat Pendidikan Islam. Bandung: Al-Maarif.

Marzuki. "Pendidikan Karakter dalam Keluarga Perspektif Islam", dalam http://staff.uny.ac.id/sites/default/files/pengabdian/dr-marzuki-mag/dr-marzuki-magprinsip-pendidikan-karakter-perspektif-Islam.pdf. Diakses pada tanggal 25 September 2015. Diakses pada tanggal 25 September 2015.

Marzuki. "Prinsip Dasar Pendidikan Karakter Perspektif Islam", dalam http://staff.uny.ac.id/sites/default/files/pengabdian/dr-marzuki-mag/dr-marzuki-magprinsip-dasar-pendidikan-karakter-perspektif-Islam.pdf. Diakses pada tanggal 25 September 2015. 
Marzuki. "Pengintegrasian Pendidikan Karakter dalam Pembelajaran di Sekolah", dalam http://staff.uny.ac.id/sites/default/files/penelitian/Dr.\%20Marzuki,\%20M.Ag./Dr.\%20M arzuki, $\% 20 \mathrm{M} . \mathrm{Ag} . \% 20$ Pengintegrasian $\% 20$ Pendidikan $\% 20$ Karakter $\% 20$ dalam $\% 20 \mathrm{Pembel}$ ajaran\%20di\%20Sekolah.pdf. Diakses pada tanggal 25 September 2015.

Mu'in, Fatchul. 2011. Pendidikan Karakter Kontruksi Teoritik dan Praktik. Yogyakarta: Ar-Ruzz Media.

Panduan Pelaksanaan Pendidikan Karakter, Pusat Kurikulum dan Perbukuan, Balitbang, Kemendiknas, 2011. Diakses pada tanggal 25 September 2015.

Nilai-Nilai Pendidikan Karakter, dalam http://www.perpustakaan.kemdiknas.go.id/Diakses pada tanggal 25 September 2015.

Peursen, A. Van. 1998. Berfilsafat Dari Konteks. Yogyakarta: Kanisius.

Purnomo, Agus. "Pendidikan Anak Dini Usia (PADU) dalam Islam", dalam http://www.pendidikankarakter.com/membangun-karakter-sejak-pendidikan-anak-usiadini/Diakses pada tanggal 25 September 2015.

Al-Qaradhawi, Yusuf. 1998. Al-Ijtihad Al-Mu'ashir. Beirut; Al-Maktab Al-Islami.

Qutb, Muhammad. 1984. Sistem Pendidikan Islam, Bandung: Al-Maarif.

Ramayulis. 2008.Imu Pendidikan Islam. Jakarta: Kalam Mulia.

Ryan, Kevin. Karen E. Bohlin. 1999. Building Character in Schools: Practical Ways to Bring Moral Instruction to Life. San Francisco: JOSSEY-BASS A Wiley Imprint.

Ash Shiddieqy, T.M.Hasbi. 1981. Pengantar Hukum Islam II.Jakarta: Penerbit Bulan Bintang.

Asy-Syafi'i. penj. Ismail Yakub. 2000. Al-Umm. Kuala Lumpur: Victory Agencie.

Asy-Syatibi, t.t. Al-Munafaqat Fi Ushul Al-Abkam. juz 2. Beirut: Dar alfikr.

Syarifuddin, Amir. 1990. Pembaharuan Pemikiran dalam Hukum Islam.

Suyanto. "Urgensi Pendidikan Karakter", dalam www.kemendiknas.go.id

Ulwan, Abdullah Nashih. penj. Emiel Ahmad. 2013. Tarbiyatul Aulad. Jakarta: Khatulistiwa Press.

Wibowo, Timothy. Langkah Awal Pendidikan Karakter, dalam http://www. pendidikankarakter.com/langkah-awal-dalam-pendidikan-karakter/Diakses pada tanggal 25 September 2015.

Zainuddin. dkk. 1991. Seluk Beluk Pendidikan Dari Al-Ghazali. Jakarta: Bumi Aksara. 